Authors manuscript for:

\title{
Fringe benefits? A review of outer suburban development on Perth's fringes in relation to state government goals concerning the natural environment and efficient transport connectivity
}

Julian Alexander Bolleter

To cite this article: Julian Alexander Bolleter (2017): Fringe benefits? A review of outer suburban development on Perth's fringes in relation to state government goals concerning the natural environment and efficient transport connectivity, Australian Planner, DOI: $\underline{10.1080 / 07293682.2017 .1319395}$

To link to this article: http://dx.doi.org/10.1080/07293682.2017.1319395

Published online: 10 May 2017. 


\title{
Fringe benefits? A review of outer suburban development on Perth's fringes in relation to state government goals concerning the natural environment and efficient transport connectivity
}

\author{
Julian Alexander Bolleter \\ Australian Urban Design Research Centre, University of Western Australia, Perth, Australia
}

ABSTRACT

This paper assesses suburban development on Perth's fringes delivered since 2004; the year Perth's first serious plan for urban consolidation was released. This assessment is conducted with reference to state government goals concerning facilitating access to the natural environment and delivering efficient transport connectivity. The paper concludes that greenfield development is producing mixed results in these areas. In this respect infill targets and policies enabling such outer suburban development warrant scrutiny.

\section{Introduction}

In the early twentieth century, the well-respected American planner Frederick Howe praised the qualities of Australia's typically suburban cities. As he proclaimed:

The great cities of Australia are spread out into the suburbs in a splendid way. For miles about are broad roads with small houses, gardens, and an opportunity for touch with the freer, sweeter life which the country offers. (Gleeson 2006, 30)

To Howe's understanding the suburbs of Perth, the capital city of Western Australia, have served us wonderfully. Substantial outdoor space has allowed suburban residents to live outdoors, in private, and to indulge in an assortment of hobbies, to have pets, to park multiple vehicles and store recreational equipment (Troy 2004, 120; Wheeler 2010, 47). They have historically allowed households to develop independence and security', particularly in relation to the production of fruit and vegetables and ecosystem services more generally. Perhaps due to these qualities a suburban ideal still lingers in the housing preferences of Perth's citizens. Indeed in a 2013 Perth housing survey, when not limited by income, $79 \%$ of those surveyed preferred a stand-alone suburban dwelling (Curtin University and Hames Sharley 2013, 16).

Despite this prevailing preference for a suburban lifestyle, the suburban model, as finds expression in all of Australia's capital cities, is arguably 'running out of steam' on a number of fronts (Gleeson 2006, 20). In particular outer suburban growth ${ }^{1}$ is seen as threatening productive rural land and biodiversity on city fringes (Adams 2016, 220), and increasing infrastructure costs, commuting times, and the concentration of economic and social vulnerabilities in farflung suburbs (Dodson and Sipe 2008, 37; Martinus 2014).

The debate about the problems of outer suburban growth can be emotive and is often not based on data. Indeed few have been more emotive than Lewis Mumford - in 1961 he declared the effect of 'sprawl' is an 'encapsulated life, spent more and more either in a motor car or within the cabin of darkness before a television set'. The entire 'wicked, sprawling, megalopolitan mess', he cheerily forecast, would 'completely demoralize mankind and lead to nuclear holocaust' (In Kunstler 1993, 10).

Given the dissonance between academic disdain for the suburbs and outer suburban development (see Bruegmann 2005), and the enduring preference for suburban living expressed by Perth's residents (Curtin University and Hames Sharley 2013, 16) this paper sets out to assess, in a rigorous and focussed manner, Perth's newest fringe suburbs from a perspective of access to the natural environment and transport connectivity - facets of urban living which contribute to urban liveability (Badland et al. 2014, 65; Ruth and Franklin 2014, 264; Thomas, Walton, and Lamb 2011). ${ }^{2}$ The aim of this process is to inform the current debate around outer suburban growth in Perth, and elsewhere, so that this debate can be focussed on data rather than emotion and presumption.

\section{Method}

Perth's overarching planning document 'Perth and Peel@ 3.5 million’ (draft) aims to achieve a city 
which is liveable, prosperous, connected, sustainable, and collaborative (Department of Planning and Western Australian Planning Commission 2015, 4). Given that the goal that future Perth is 'liveable' is arguably too broad for adequate discussion in a single journal paper, and 'prosperity' and 'collaborative' are not first and foremost spatial planning issues, this paper focusses on whether the predominate form of urban development in Perth, greenfield development, is delivering the goals that the State Government is aspiring to in relation to being 'sustainable' and 'connected' (Department of Planning and Western Australian Planning Commission 2015, 4).

In more detail the goal of connectivity entails 'a well serviced, accessible and connected city with strong regional, national, and international links. People will be able to move freely around the city via a choice of efficient transport modes' (Department of Planning and Western Australian Planning Commission 2015, 4). Given the necessary brevity of this paper I will focus principally on the delivery of public and active transport connectivity on Perth's fringes. The goal of sustainability entails 'Perth will responsibly manage its ecological footprint and live within its environmental constraints, while improving our connection with and enjoyment of the natural environment' (Department of Planning and Western Australian Planning Commission 2015, 4). In this respect I will focus principally on connection with the natural environment on Perth's fringes through the delivery of regional open space (ROS), public open space (POS), and private open space.

The overarching research question structuring this evaluation is:

To what degree has greenfield development, in Perth since 2004, delivered the access to, nature and the transport connectivity that the Western Australian State Government is aspiring to through its planning for Perth's growth?

The research methods employed to answer this question are twofold. Firstly, an extensive geospatial mapping exercise, focussed on the Perth metropolitan region, is conducted using datasets for greenfield development, remnant bushland, regional, and POS types, bushfire prone areas, public transport routes, car ownership and usage - amongst others. Subsequently a 'modelling and correlational strategy' - which involves identifying relationships between observed variables (Swaffield and Deming 2011, 37) - is used to consider correlations, or otherwise, between the datasets and areas of recent greenfield development (e.g., whether train stations are within walking distance of where the majority of new fringe housing). This allows an evaluation and written assessment as to whether the goals of 'Perth and Peel@3.5 million' (Department of Planning and Western Australian Planning Commission 2015) are actually being achieved.

\section{Greenfield development in Perth}

Since Perth's 2004 'Network City' plan, Perth has had metropolitan scale planning which aimed to consolidate development within existing urban areas (Department of Planning and Western Australian Planning Commission 2015, 12). This narrative of urban densification was retained in Perth's current plan 'Perth and Peel@3.5 million' (Department of Planning and Western Australian Planning Commission 2015), despite a drop in the infill development target from $60 \%$ to $47 \%$ (Holling and Haslam McKenzie 2010, 280). Despite much being made of the need for urban infill in these documents, a large amount of outer suburban development continues. Indeed, historically the net infill rate for the Perth metropolitan and Peel regions has hovered around $32 \%,{ }^{3}$ meaning that a substantial $68 \%$ tends to be outer suburban growth (Department of Planning and Western Australian Planning Commission 2014, 107).

\section{Why is outer suburban development dominant?}

Firstly, the reason that a high percentage of outer suburban development, has and is occurring, reflects the difficulties of achieving infill development in Perth, in particular in the form of Activity Centres and Activity Corridors, the flagships of state government urban infill policy. This is in turn reflective of the uncertainties generated by a lack of community support for urban infill and the difficulties of coordinating infrastructure provision, amongst other factors (Rowley and Phibbs 2012).

On the other side of the ledger, the land development and project home industries in Perth operate as a well-oiled machine for delivering new suburbs - in part because they form a powerful lobby group which has historically (across all Australian cities) been well connected to government (Dovey and Woodcock 2014, 8). By way of example, in Perth land developers' 'commonly employ private sector planning consultants to lodge rezoning applications and appeal rezoning refusals, so as to enable further urban frontier expansion' (Adams 2010, 45). Evidence of this is that 56\% of all urban rezoning to the Metropolitan Region Scheme (MRS) between 1970 and 1990 occurred in sites which were not in the designated growth corridors (Adams 2010, 39). Furthermore, between 1990 and 2005 further examples of urban break-out occurred throughout the metropolitan area (Adams 2010, 39). In this context the state Department of Planning is hindered by the fact that they own clittle of the principal commodity it is attempting to regulate - urban land' and as such on certain occasions has at some points been 'heavily influenced by actors outside of the centralised planning structure' (Adams 2010, 47). Due in part to this situation, there is a divergence between the 
planning and rhetoric of Perth as a compact city and the expansive suburban development which is occurring on the ground.

\section{Existing literature on greenfield development in Perth}

This paper complements and extends research concerning Perth's outer suburbs. Such literature includes 'Unsettling suburbia: the new Landscape of oil and mortgage vulnerability in Australian cities' (Dodson and Sipe 2008) which focussed on mortgage stress and potential petrol price increases associated with a peak oil scenario across all Australian cities. Local advocacy group, 'The Committee for Perth' have also produced reports concerning the growing divide between rich and poor suburbs (a number of which are on the fringe) in Perth (Martinus 2014, 1). This research extends and to a degree updates both of these research projects. Adams (2010) and Alexander and Greive (2010) have written about the state government's spatial plans for 'taming' outer suburban growth however the connectivity and sustainability of the resultant outer suburbs was not discussed in detail. Finally Anthony Duckworth-Smith has written in detail about the quality of suburban and urban living in Perth - and used a combination of both to propose new models for residential infill (Duckworth-Smith 2016). The research showcased in this paper differs in that it is specifically focussed on only two of the criteria which form part of a broader question of liveability, whereas Duckworth-Smith's research considers a far greater breadth of criteria, but in less detail.

\section{Greenfield development and the natural environment}

The following sections of this paper evaluate greenfield development in Perth in relation to the Western Australian State Government's own goal to provide access to the natural environment (Department of Planning and Western Australian Planning Commission 2015, 4).

\section{Access to nature}

'Contact with nature' is regarded as an all-encompassing requirement of 'urban landscapes' around the world (Arvola and Pennanen 2014, 8), a sentiment also strongly subscribed to by Perth's residents (Curtin University and Hames Sharley 2013, 68). Of course 'nature' is a highly subjective term that needs further definition. Landscape historian John Dixon Hunt has split nature into three definitions, respectively first nature, second nature, and third nature. In his definition first nature is the untouched nature of wilderness, second nature refers to cultural landscapes which can be taken to include all agricultural landscapes and the miscellaneous landscapes of our cities (e.g., freeway reserves or national parks), and 'third nature' a category which includes all manicured parks and gardens (Hunt in Thompson 2011, 19). This section will discuss access to bushland and ROS which can be considered within Hunt's 'second nature' category, and access to POS and private open space which can be considered 'third nature'.

\section{Access to nature - bushland and ROS}

Perth sits within the threatened Southwest Australia biodiversity hotspot, an exceptionally biodiverse regional context ${ }^{4}$ (Conservation International 2014). Despite the high levels of biodiversity the Southwest biodiversity hotspot sustains, it is much diminished in comparison to its pre-European annexation condition - indeed it has already lost the majority of its original endemic vegetation (South West Australia Ecoregion Initiative 2006, 17), a situation which is reflected in the fact that the region has a greater number of species of threatened plants (2500) than most countries of the world (Hopper and Gioa 2004, 604).

In the Perth metropolitan region, as opposed to the broader hotspot, this clearing has primarily been due to outer suburban development (Ramalho et al. 2014, 143) (Figure 1). Indeed nearly 900 hectares of native vegetation was cleared from the Perth metropolitan area, per year, between 1998 and 2004, and 15,000 hectares was approved for clearing in 2005-2006 alone (Weller 2009, 125).

The release of the state government's long-awaited 'Perth and Peel Green Growth Plan for 3.5 million' (draft) may however herald a transformation in the relationship between the city and the biodiversity hotspot (Government of Western Australia 2015). The Green Growth Plan is a whole of government initiative to deliver a 'comprehensive' environmental program for the protection of both Commonwealth matters of national environmental significance and State environmental values (Government of Western Australia 2015). The plan embodies two main aims: to protect remnant bushland, and wetlands in 170,000 hectares of new and expanded reserves within and adjacent to the Perth and Peel regions, and to reduce bureaucratic hurdles for land developers by achieving upfront Commonwealth environmental approvals for urban development within designated areas across the Perth and Peel regions. (Government of Western Australia $2015,3)$. While undoubtedly positive achievements which should be recognised - a question remains as to the implications of clearing a further 9700 hectares (3\% of the Swan Coastal Plain in the Perth and Peel region) of remnant bushland which is not protected by the conservation reserves. Furthermore, only time will tell how a plan that enforces restrictions on the powerful land development lobby will endure (See Adams 2010, 39). 


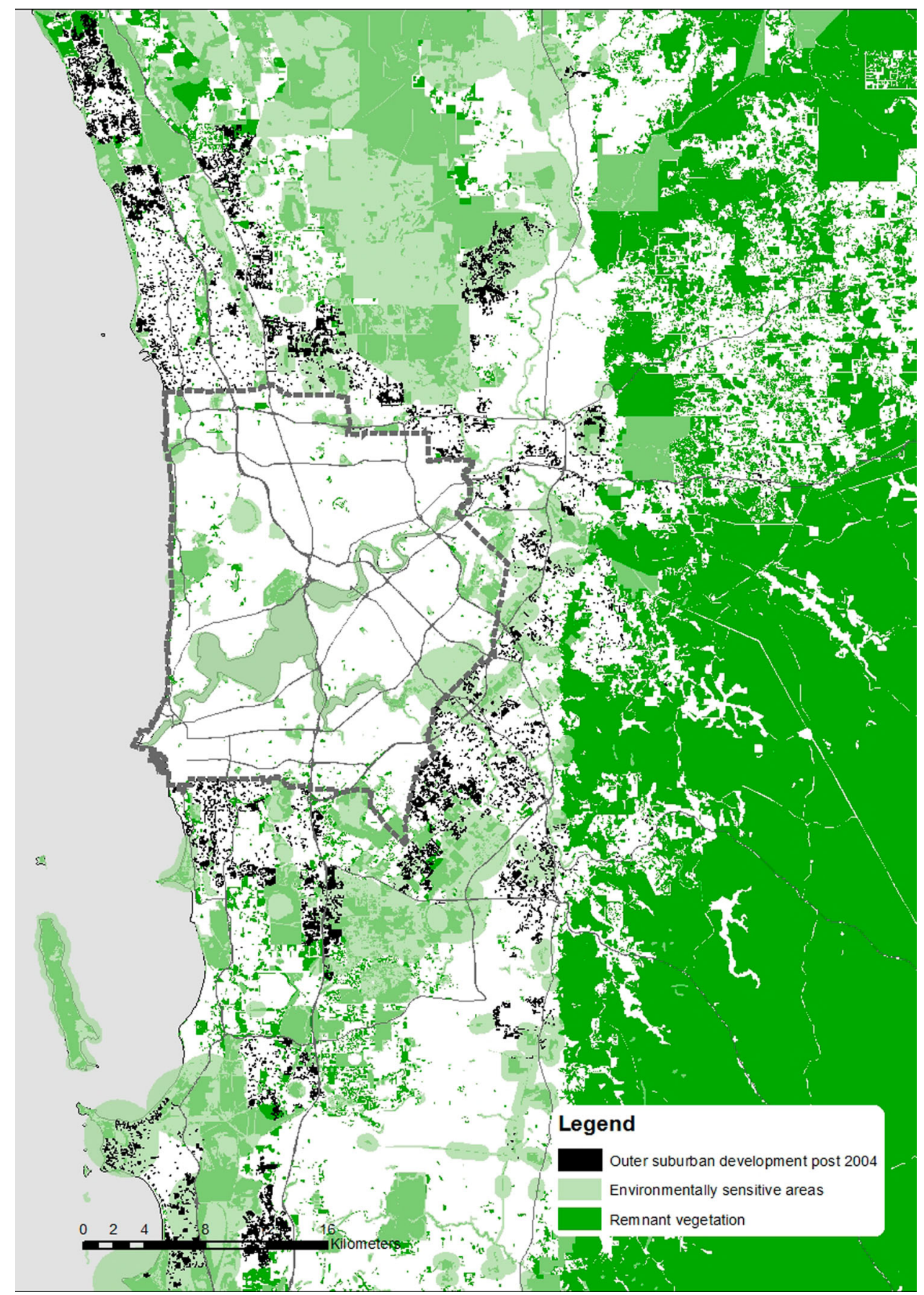

Figure 1. In the Perth metropolitan region this clearing has primarily been due to outer suburban development. This map juxtaposes suburban develop since 2004 (Landgate) with 'environmentally sensitive areas' (Department of Environment Regulation) and remnant vegetation (Western Australian Local Government Association).

Regardless, through the existing ROS reserves and those proposed as part of the Green Growth Plan, outer suburban residents are reasonably well serviced with areas of natural environment (Figure 2). While POS at the local, neighbourhood and district scales has 'accessibility catchments' of 300,800 , and 2000 metres delineated as part of the Liveable Neighbourhoods code (West Australian Planning Commission and Department of Planning 2015, 20) ROS such as conservation reserves is typically considered to be an attraction that users will drive or use public transport to reach (Department of Sport and Recreation 2012,
14). Certainly mapping shows that for many residents it is outside of an 800 metres, 10-minute walkable catchment, but that is to be expected.

Outside of the 'natural environment' which is inside designated conservation zones, 9700 hectares of remnant vegetation, 23,000 hectares of pine plantations, and substantial areas of agricultural land remains slated for future outer suburban development. As the progressive suburban development of these areas unfolds, new residents will, for a time, have access to such landscapes which are typically perceived as to some degree 'natural' (or second nature by Hunt's definition) 


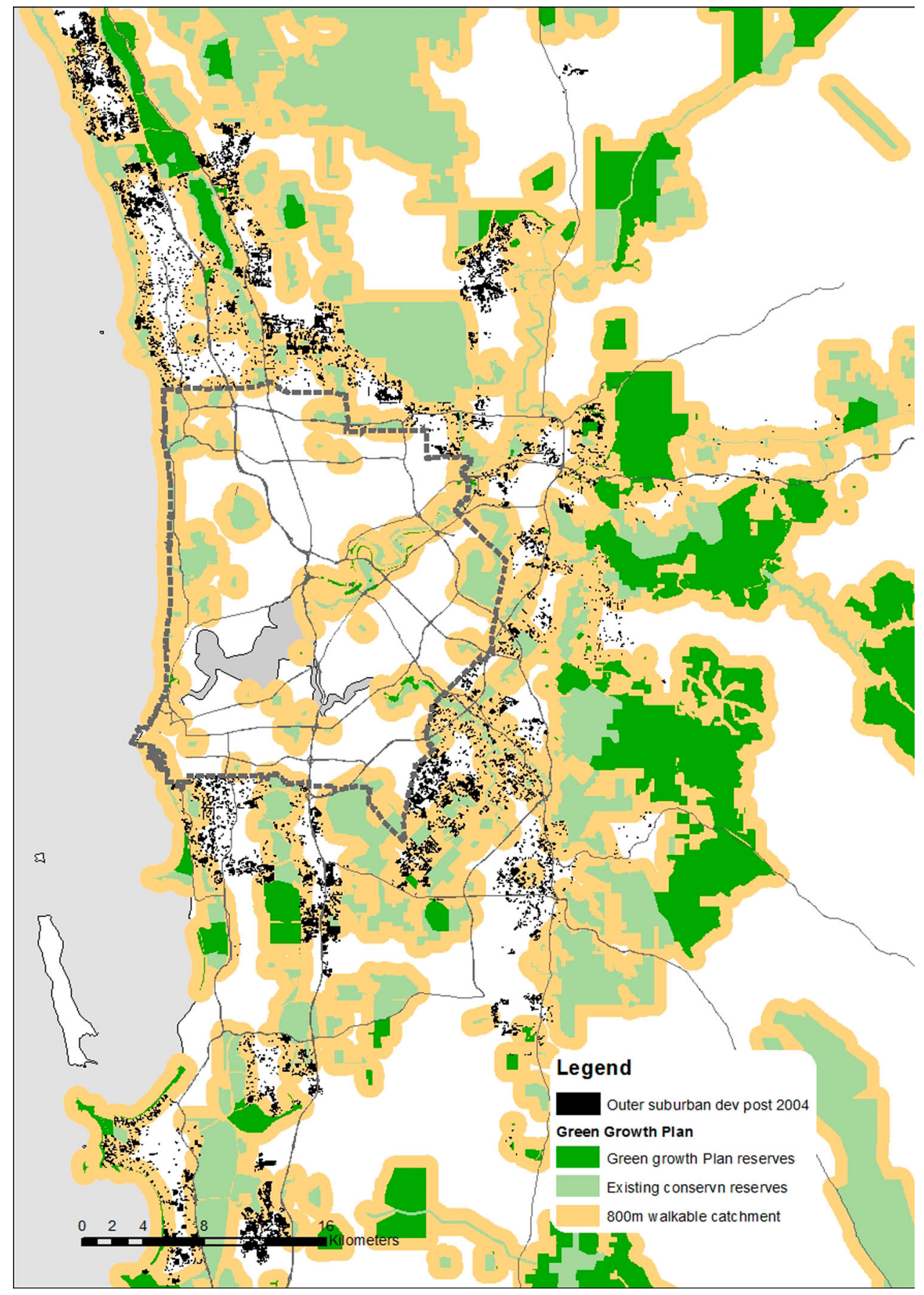

Figure 2. Through the existing ROS reserves and those proposed as part of the Green Growth Plan (Government of Western Australia 2015) outer suburban residents are reasonably well serviced with areas of natural environment.

however as development occurs their proximity will inevitably be diminished. As has been the practice to date, these cleared landscapes are often reconstituted in the process of suburban development. Richard Weller describes the irony in that 'in deference to a "sense of place", the landscape that the new suburb almost inevitably erases is returned to the new development as thematic veneer, a symbolic pastiche or hapless remnant of its former self (Weller 2008, 247).

\section{Bushfires}

While access to nature in the form of remnant bushland conservation reserves arguably meets state government goals in this respect, on Perth's fringe, these same suburban areas are threatened by bushfires. Part of the reason for fire risk on the fringe is the complexity of the edge between suburban development and remnant bushland which increases the length of the interface and as such the vulnerability of houses (Department of Planning and Western Australian Planning Commission 2015, 56). It is predicted that Perth will experience more frequent bushfires as climate change causes Terra Australis to become 'Terror Australis, a blast furnace of drought, heat and capricious tempests' (Gleeson 2006, 15) and indeed the tragic Canberra fires of 2003 and the Black Friday fires of 
2009 (which came dangerously close to Melbourne's suburban edge) serve as a warning in this respect (Gleeson 2010, 21). Recent mapping of 'fire prone areas' for the Perth region by the Department of Fire and Emergency Services (FESA) show outer suburban areas to be particularly vulnerable (2016) (Figure 3). Such increasing insecurity can only be argued as diminishing the benefits of access to natural areas in Perth's outer suburbs. Moreover, the clearing of vegetation necessitated by mitigating bushfire risk will also likely diminish the perceived connection of residents to nature.

\section{Access to nature - POS}

The provision of POS is regarded as a vital component of urban liveability (McCrea and Walters 2012, 193). An analysis of parks in outer suburban settings on Perth's fringe - which conform to Hunt's 'third nature' (Hunt in Thompson 2011, 19) - reveals that houses generally are within the 300-metre walk of a park (Figure 4). This is not surprising given that New Urbanist developments on the fringe often use parks as a major selling point - and the 'Liveable Neighbourhoods' design code governing outer suburban development calls for the creation of smaller, yet more accessible parks (West Australian Planning Commission and Department of Planning 2007).

The trade-off of park size against accessibility has, according to some observers, however occurred at the cost of park user's ability to 'lose themselves' in the park experience (Syme, 2016) as well as participate in active recreation in Perth's outer suburbs. Researchers Garry Middle and Marian Tye concluded that many of the New Urbanist outer suburbs resulting from the 'Liveable Neighbourhoods' code (such as Ellenbrook) have a lower percentage of the suburb available for active recreation (Middle and Tye 2011,4). Indeed to their calculation Perth's middle ring suburbs provide $1.38 \%$ of their area for active recreation while New Urbanist outer suburbs provide 0.79\% (Middle and Tye 2011,4). One presumed effect of this has been high physical inactivity levels in Perth's outer suburbs (PHIDU Torrens University Australia 2016) (Figure 5). This mapping ${ }^{5}$ from the Social Health Atlas (PHIDU Torrens University Australia) reveals that in outer suburban areas, above $30 \%$ of people were largely physically inactive something which could be tied back to a shortage of active recreation space, amongst other transport-related factors discussed later.

While the active versus passive balance achieved in outer suburban parks is hotly contested they are also increasingly at threat from irrigation water shortages. With more and more groundwater resources becoming fully allocated or over-allocated, ${ }^{6}$ especially in the northern and eastern urban growth areas, groundwater from the superficial aquifer for irrigation of POS (and other landscapes) is no longer available in some areas
(Figure 6). Short of using recycled wastewater or resorting to potable water supplies (sourced largely from energy intensive seawater desalination) for irrigation, these parks will need to be reconfigured at least in part as xerophytic landscapes. The need for this adaption is borne out by data from the Centre of Built Environment and Health concerning POS in outer suburbs which measured that $98 \%$ of the parks in Ellenbrook (a typical Liveable Neighbourhoods designed outer suburb) constituted irrigated turf (Centre for the Built Environment and Health and Gaia Resources 2013).

While the transformation of such parks into a xerophytic form may mean that their design resonates more with remnant bushland (and Hunt's first/second nature categories), as these suburbs become hotter and drier with the predicted effects of climate change in Perth (Department of Water 2016, 2), ${ }^{7}$ the need to be able to maintain irrigated green space as a balancing mechanism will become increasingly important for ensuring that the parks are 'attractive'. This importance is due to the fact that irrigated 'naturalistic' green spaces tend to provide more shade, mitigation of urban heat island and minimisation of temperature extremes (McDonald 2015, 12). This issue of water for irrigation remains unresolved as part of a much bigger picture of water shortages to be experienced in Perth in this century (Department of Water 2016, 5).

\section{Access to nature - private open space}

The lifestyle Australia offers is well known for the opportunity it affords to 'live outdoors, in private' - a situation enabled by freestanding houses with front and back gardens, set out at a typically low density (Wheeler 2010, 47). An Australian predilection for private open space is for good reason, home gardens (part of Hunt's third nature) have been shown to be a major contributor to the quality of life (Syme, Fenton, and Coakes 2001, 161). Among other functions, the residential gardens provides for a sense of connection to nature, active and passive recreation as well as the space to cultivate fruit and vegetables. Furthermore, ongoing psychological benefits of private gardens have also been well recorded (Kaplan in Syme, Fenton, and Coakes 2001, 161).

Counter to such evidence, outer suburban development on Perth's fringes - in accordance with New urbanist preference for urban compactness - tends to provide much less garden area per person, than an un-subdivided 'classic' quarter acre block that tended to provide 1000 metres squared per household (Seddon 1994, 27). In a comparatively typical outer suburban development such as Ellenbrook, a large number of lots are less than 300 metres squared and indeed some micro-lots will be as small as 80 metres squared (Figure 7). This in combination with a predilection for, sometimes, large houses means that private open 


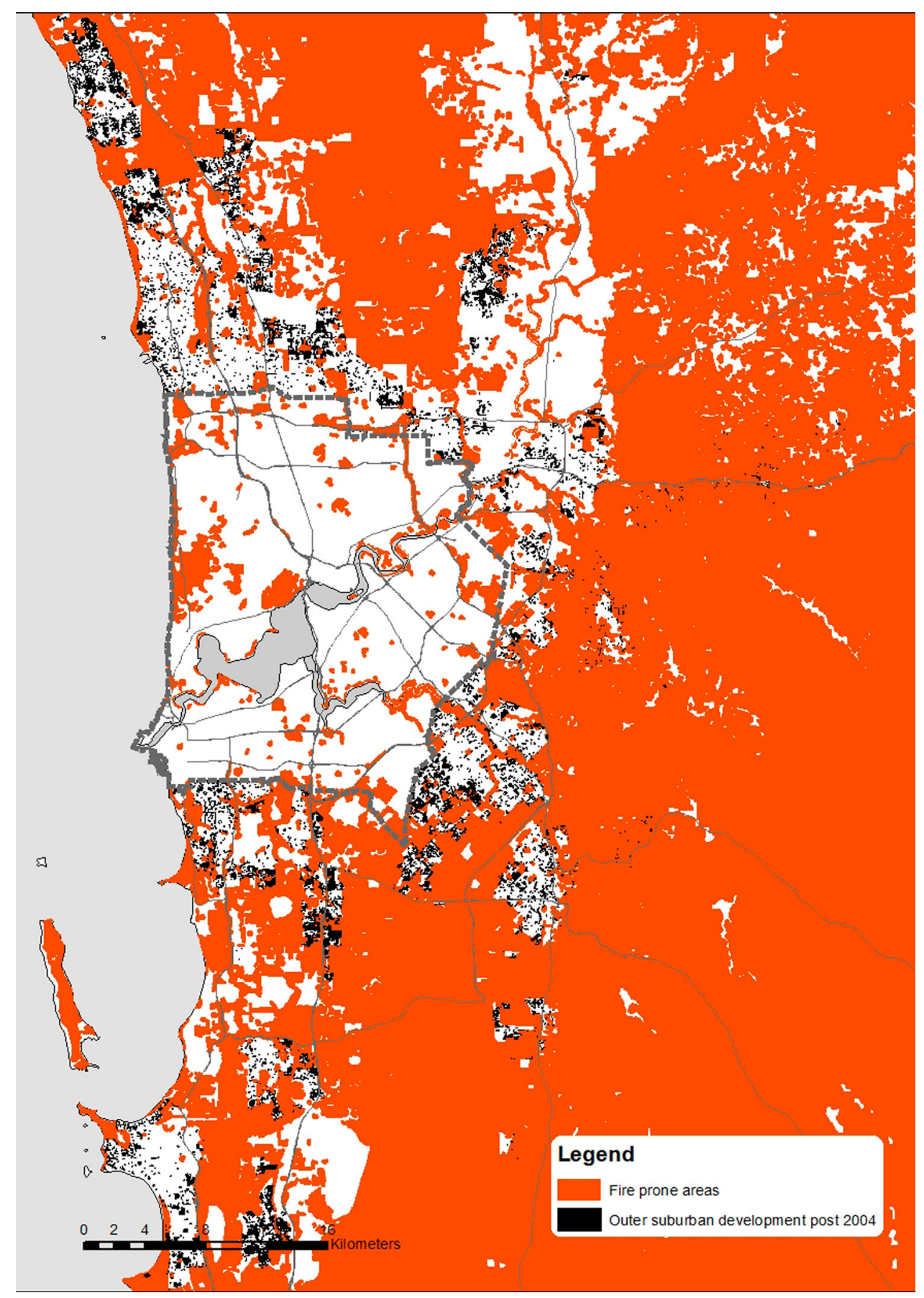

Figure 3. Recent mapping of 'fire prone areas' for the Perth region by the Department of Fire and Emergency Services (FESA) show outer suburban areas to be particularly vulnerable (2016). Such increasing insecurity can only be argued as diminishing the liveability of Perth's outer suburbs. Moreover, the clearing of vegetation necessitated by mitigating bushfire risk will also depress liveability in other respects by in part diminishing the perceived connection of residents to nature.

space provided is significantly reduced. Compounding this situation much of the private open space that is provided in such small lot situations is residual space, generated by the State Government controlled Residential Design Codes (R-codes) which dictate a minimum setback of one point five metres between lot lines and built form (State of Western Australia 2010) which tends to result in confined strips of private open space.

The result of such small lots and high degree of site cover by houses is that an urban forest is unlikely to form as the many of Perth's outer suburban developments mature. This is because generally more than $60 \%$ of the trees which comprise an urban forest are located on such private land (Fisher in Brunner and Cozens 2013, 234), a commodity much reduced in Perth's outer suburbs built since 2004. The effects of this lack of urban forest are potentially serious as urban forests help to maintain a day-to-day connection to nature for residents, as well as enhance biodiversity, realise energy savings through mitigating temperature extremes, and purify air and stormwater (Brunner and Cozens 2013,234). Furthermore as lot sizes have become narrower, large driveway cross overs have 


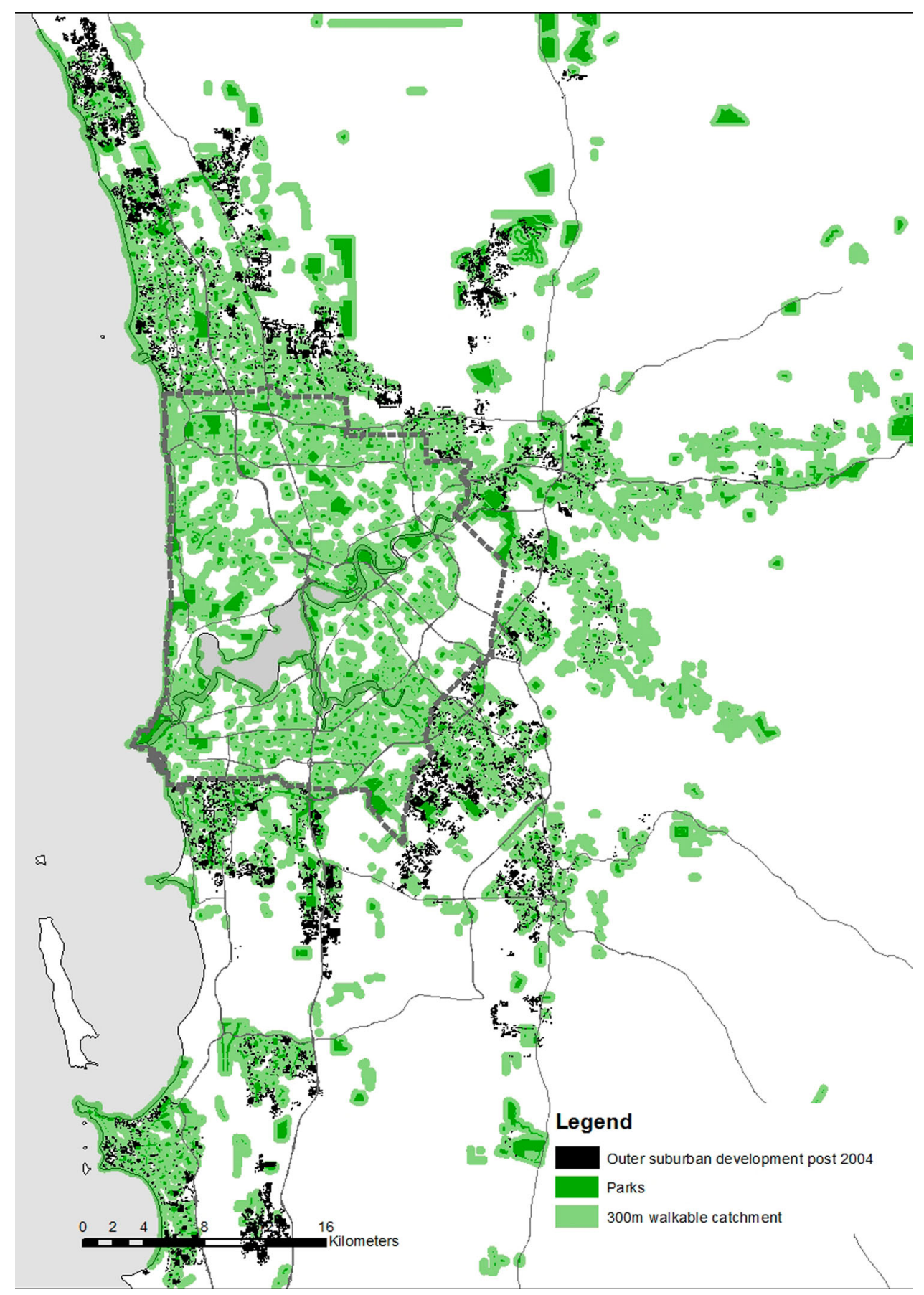

Figure 4. An analysis of parks in outer suburban settings on Perth's fringe reveals that most, but not all, houses are within the 300 metre walk of a park. This is not surprising given that New Urbanist developments on the fringe often use parks as a major selling point - and the 'Liveable Neighbourhoods' design code governing outer suburban development calls for the creation of smaller, yet more accessible parks (Park polygons courtesy of Department of Planning).

tended to reduce opportunities for street tree plantings - plantings that may have helped to bolster the lack of trees in backyards.

By way of conclusion to this first section, while outer suburban development delivered in Perth since 2004 can be seen to providing a connection to nature at a broader regional scale, at the lot scale this access to nature has been diminished. Of course these two scales are connected - without greater density at the lot scale almost inevitably greater destruction of remnant vegetation would be occurring at the regional scale. This represents a wicked problem in which various outcomes at different scales tend to contradict each other and defy easy resolution. This said the provision of a significantly reduced private domain, on the fringe of a city where access to space is generally regarded as a necessary trade-off could have worrying effects on access to natural areas particularly over the longer term.

\section{Transport connectivity}

The following section explores the state government's goal of connectivity (Department of Planning and Western Australian Planning Commission 2015, 4) in 


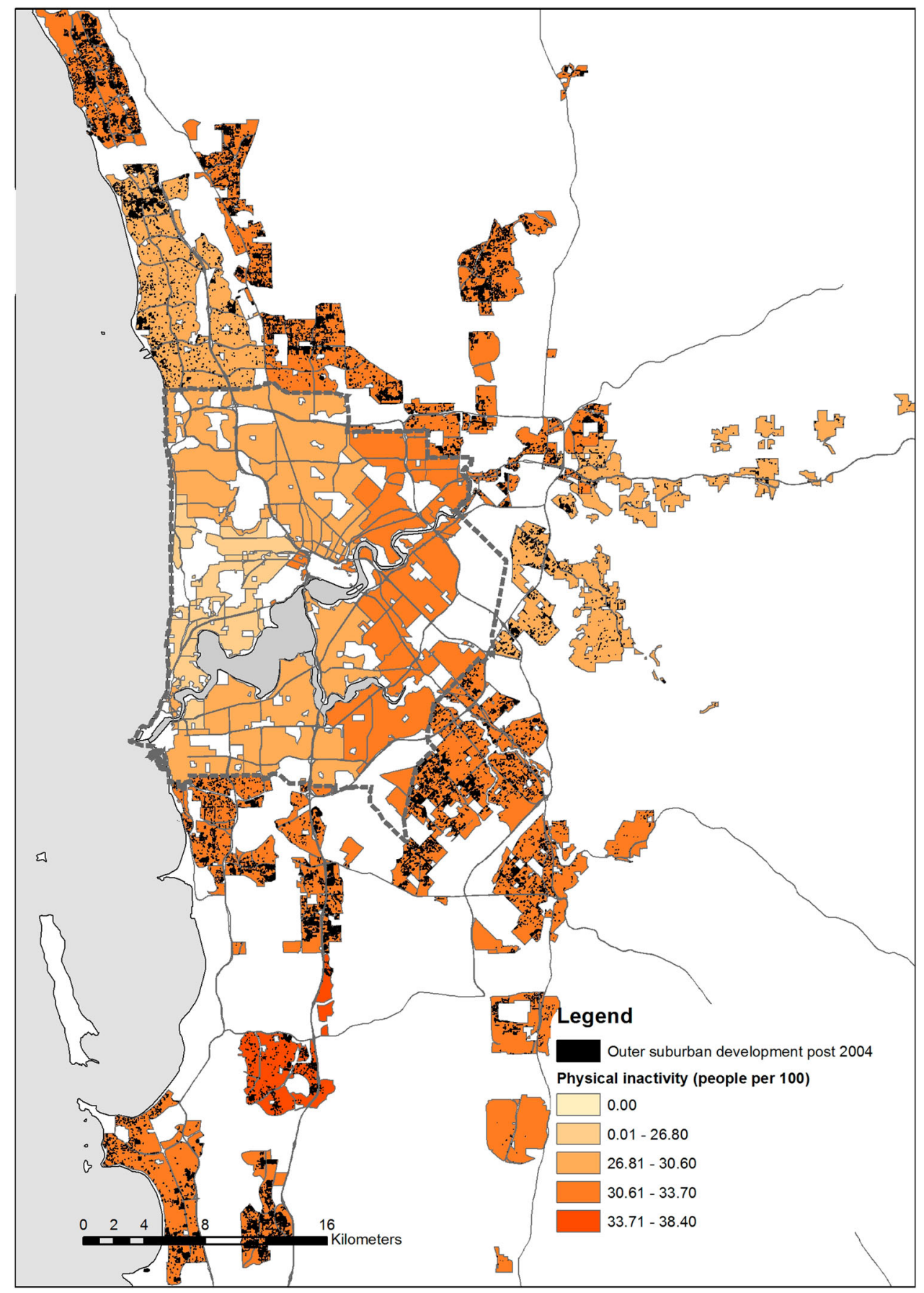

Figure 5. Researchers Garry Middle and Marian Tye concluded that many of the New Urbanist outer suburbs resulting from the 'Liveable Neighbourhoods' code have a lower percentage of the suburb available for active recreation. Indeed to their calculation Perth's middle ring suburbs provide $1.38 \%$ of their area for active recreation while New Urbanist outer suburbs provide $0.79 \%$. One presumed effect of this has been high physical inactivity levels in Perth's outer suburbs (PHIDU Torrens University Australia).

relation to principally public and active transport connectivity at the metropolitan scale.

Long commutes by private car has been linked to reduced available time for forging and maintaining social connections, and are 'linked to lower overall wellbeing and life satisfaction' (Kelly et al. 2012, 16). Presumably as a result of this situation, the housing preferences expressed by Perth's residents in comparatively recent surveys, show $71 \%$ of respondents surveyed in the 'The Housing We'd Choose' study regarded a dwelling being near public transport as important (Curtin University and Hames Sharley 2013, 19).
In apparent contradiction to this finding, Perth remains a stubbornly car-dominated city, indeed over the last four decades, and it now has 'more cars per capita than any other Australian capital city with some 83 vehicles per 100 people' (Department of Planning and Western Australian Planning Commission 2015, 46). The dominance of cars is particularly pronounced in the outer suburbs. Evidence for this is reflected in the percentage of people who drove to work, a figure which is often well over $70 \%$ in the outer suburbs (Figure 8), and in car ownership, with most outer suburban Local Government 


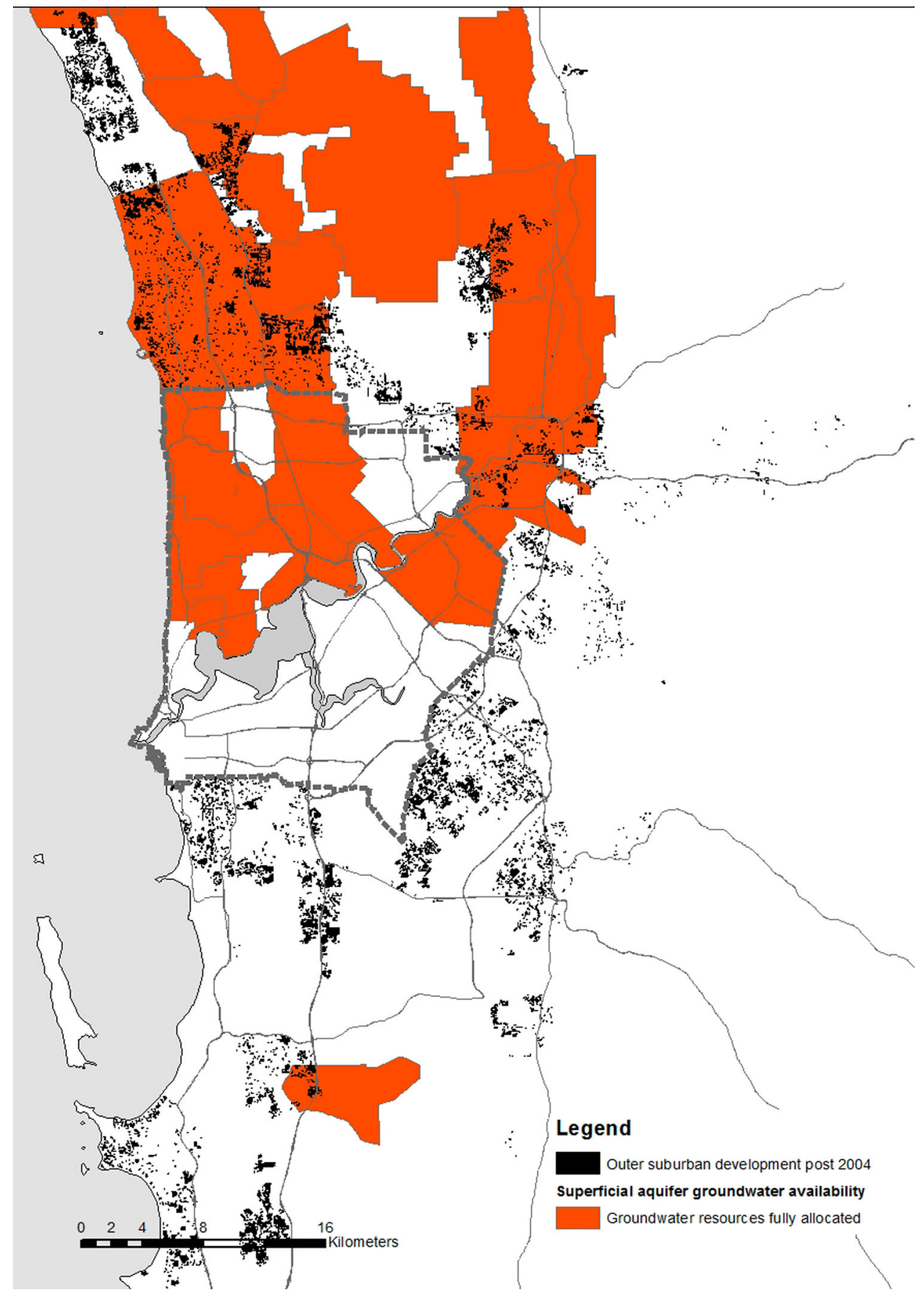

Figure 6. With more and more groundwater resources becoming fully allocated or over-allocated, especially in the northern and eastern urban growth areas, groundwater from the superficial aquifer for irrigation of POS (and other landscapes) is no longer available in some areas (Essential Environmental).

Areas (LGAs) averaging two or more cars per dwelling (Figure 9), a high figure compared to inner and middle ring suburbs.

\section{Access to the train network}

Vehicular dominance in Perth's outer suburbs can be in turn explained by the limited reach of public transport. Perth's rail system, a major structuring element of Perth's public transport system, consists of five rail lines projecting from the city's centre. Much of the outer suburban development that is being delivered is located in the substantial wedges between the radiating rail lines. While the current Liberal state government promised a heavy rail connection to the outer suburban 'break-out' suburb of Ellenbrook (Alexander and Greive 2010,59), which would have lent an intermediate axis to this radiating structure, this promise has been broken due to spiralling state debt. This situation is symptomatic of part of a broader emerging reality of infrastructure deficits on the fringes of Australian cities (Adams 2016, 217).

In part as a result, mapping of Perth's train stations in combination with recent outer suburban development which has occurred since 2004, reveals that little 


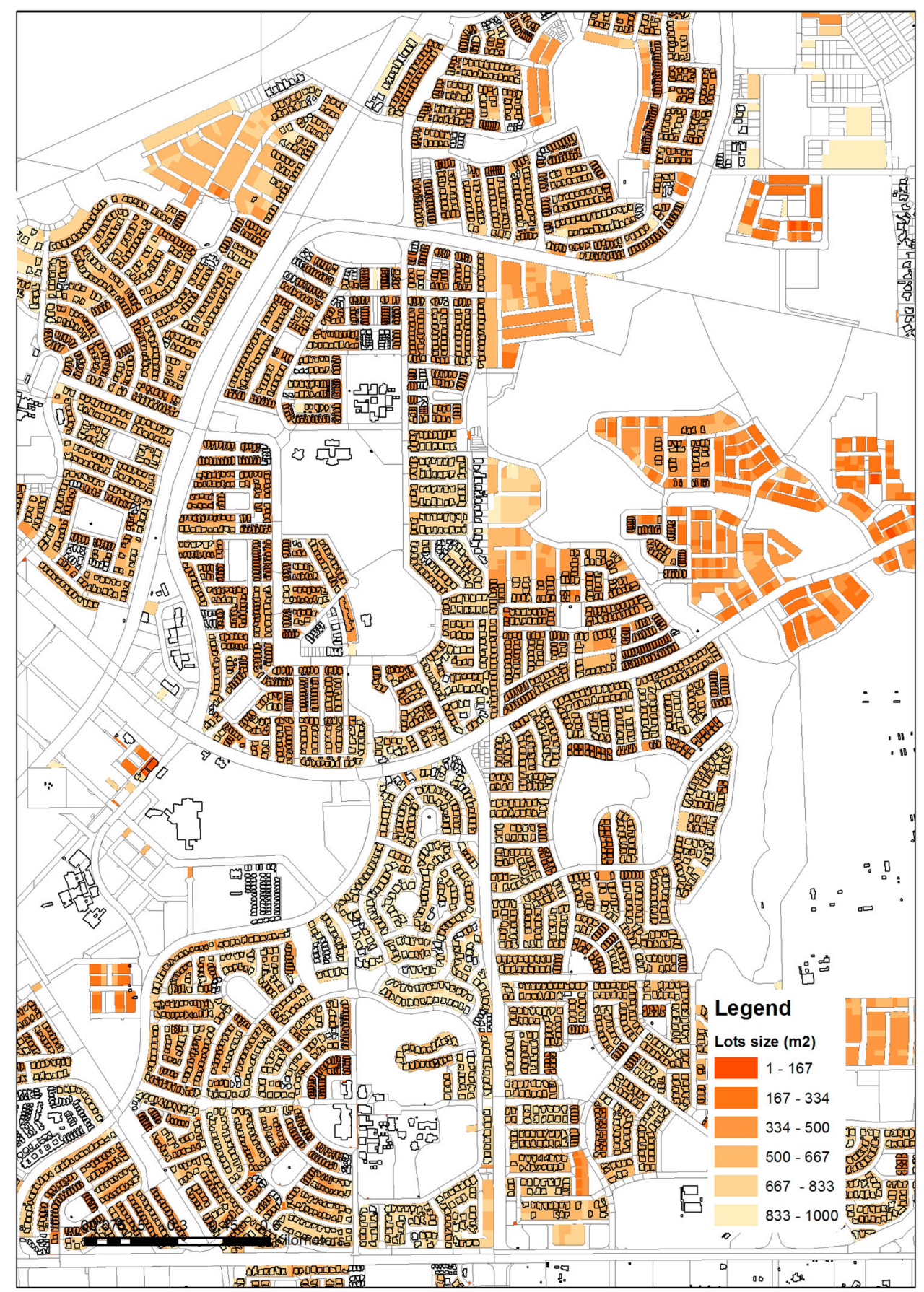

Figure 7. Outer suburban development on Perth's fringes - in accordance with New Urbanist preference for urban compactness tends to provide much less garden area per person, than an un-subdivided 'classic' quarter acre block that tended to provide 1000 metres squared per household. In a comparatively typical outer suburban development such as Ellenbrook, a large number of lots are less than $\mathbf{3 0 0}$ metres squared and indeed some micro-lots will be as small as 80 metres squared.

of this urban development is within a comfortable walk of train stations- in this map shown as an 800-metre or 10-minute walk (Figure 10). Certainly outer suburban residents are not being rewarded for accepting higher density living with rail connectivity within a comfortable walk.

\section{Access to the bus network}

While significantly more of the area of recent outer suburban development is serviced by bus routes than trains, the bus system generally prioritises coverage (meaning short walking distances and the minimisation of bus transfers) over the 'frequency and legibility of the service' (Mees and Dodson 2011, 18) - perhaps explaining the dominant use of vehicles for commuting to work from the outer suburbs. While access to bus services in such outer suburbs is less than ideal on weekdays (Figure 11), on weekends, it becomes untenable for most journeys. For instance relying on the bus system to get from Ellenbrook to Perth on a Sunday afternoon (inclusive of a typical 5-minute walk to a bus stop) will take seventy minutes (Transperth 2016) - well outside the general societal preference to live within a half hour trip of a city centre, a 


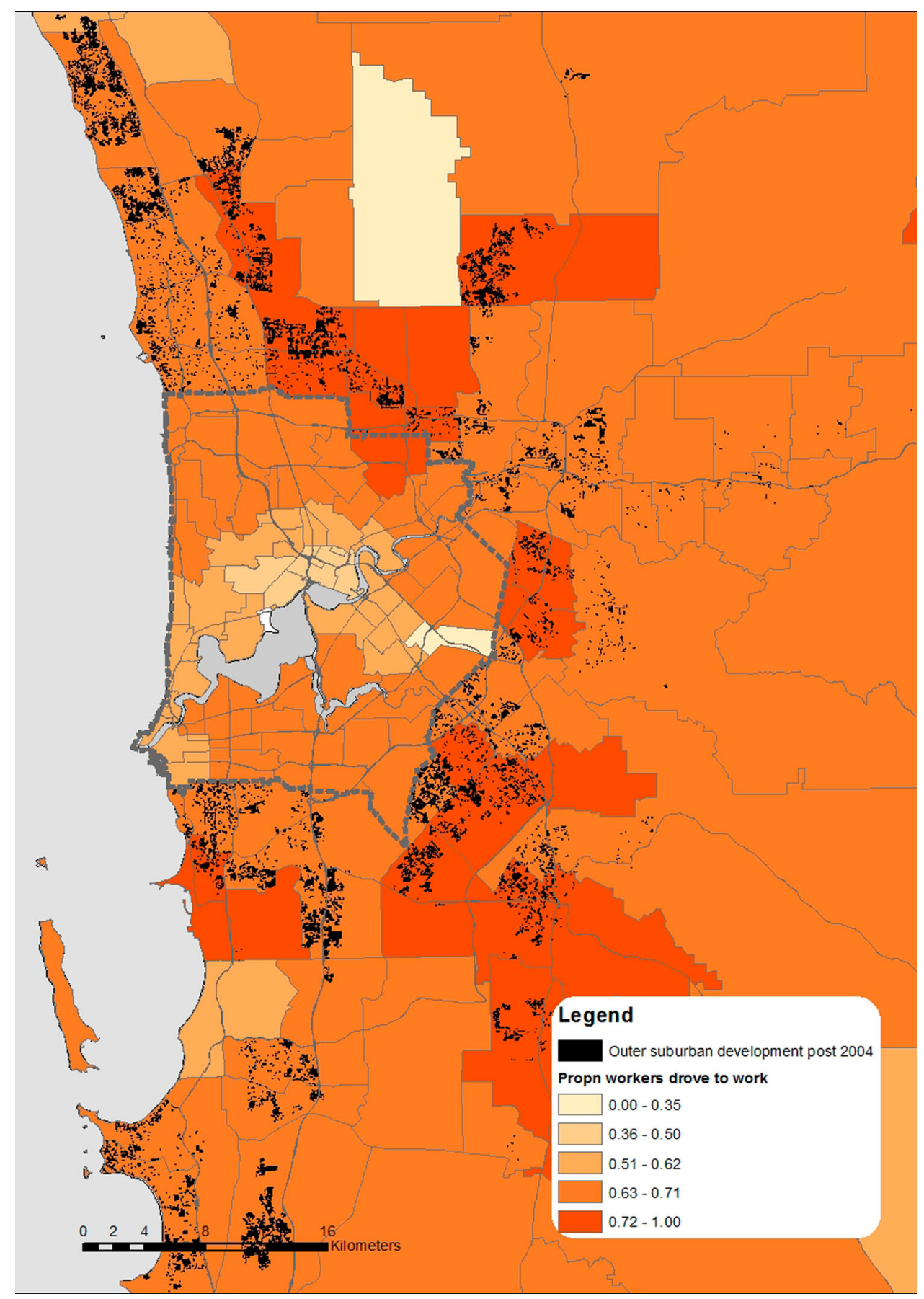

Figure 8. The dominance of cars is particularly pronounced in the outer suburbs. Evidence for this is reflected in the percentage of people who drove to work, a figure which is often well over $70 \%$ in the outer suburbs (Australian Bureau of Statistics 2013).

preference commonly known as Marchetti's constant (Grace, Kinghorn, and Thakur 2016, 2).

\section{Access to bicycle networks}

Finally vehicular dominance in Perth's outer suburban developments is compounded also by an often disconnected and thinly spread bike network, and the significant distance bicycle riders need to cover to even get to major public transport nodes (Figure 12). Residents living closer to the city have a comparatively connected and accessible bicycle network; however this privilege is not extended to the outer suburbs. While less effort has been expended to understand the numbers of people commuting using bicycles in the outer suburbs, the data available shows that bicycle commuting is much less common in the outer suburbs than in the inner and middle suburbs.

In response to these issues confronting rail, bus, and cycling infrastructure provision the State Government has recently released 'Transport@3.5 million' (Department of Transport, Public Transport Authority, and Main Roads WA 2016) which provides a long term plan for transport infrastructure as Perth's population approaches 3.5 million around mid-century. This plan embodies admirable intentions to expand Perth's 180-kilometre rail network to nearly 300 kilometres, 


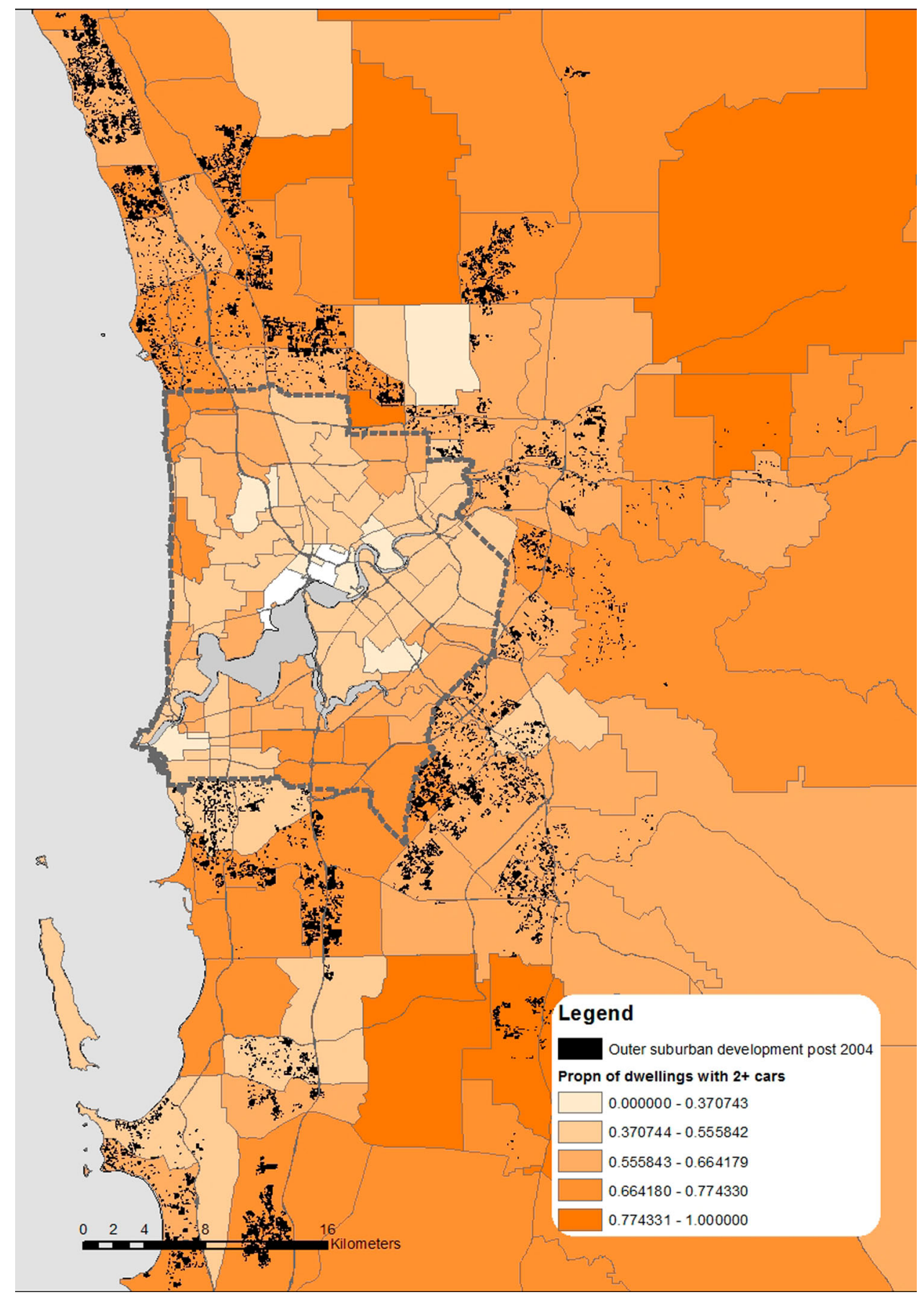

Figure 9. Most outer suburban LGAs average two or more cars per dwelling, a high figure compared to inner and middle ring suburbs (Australian Bureau of Statistics 2013).

and the cycle paths from today's 172 kilometres of offroad commuter cycle ways to around 850 kilometres (Department of Transport, Public Transport Authority, and Main Roads WA 2016) - in part to better service current outer suburbs. The issue with this uncosted plan is not with its worthy intentions but rather how it will be delivered in relation to a perilous state debt situation (O'Connor 2015).

\section{Access to transport futures}

Given the apparent relative inability of state and local governments to effectively service outer suburban areas with public transport and bicycle networks, some commentators refer to the potential of Fully Automated Vehicles (FAV) to play a role. Indeed Tony Davis explains in a recent publication: 'self-driving cars will be on sale in just four years, and there is broad consensus they will save energy and lives, liberate time for leisure and work, and transform the economy' (2016, 179). Nonetheless this period of transformation to ubiquitous FAVs is predicted to last until at least 2040-2050 (Somers and Weeratunga 2015, iii).

The literature suggests that AVs are likely to provide the greatest benefits to outer suburban commuters using freeways, where the 'ride will be smooth and 


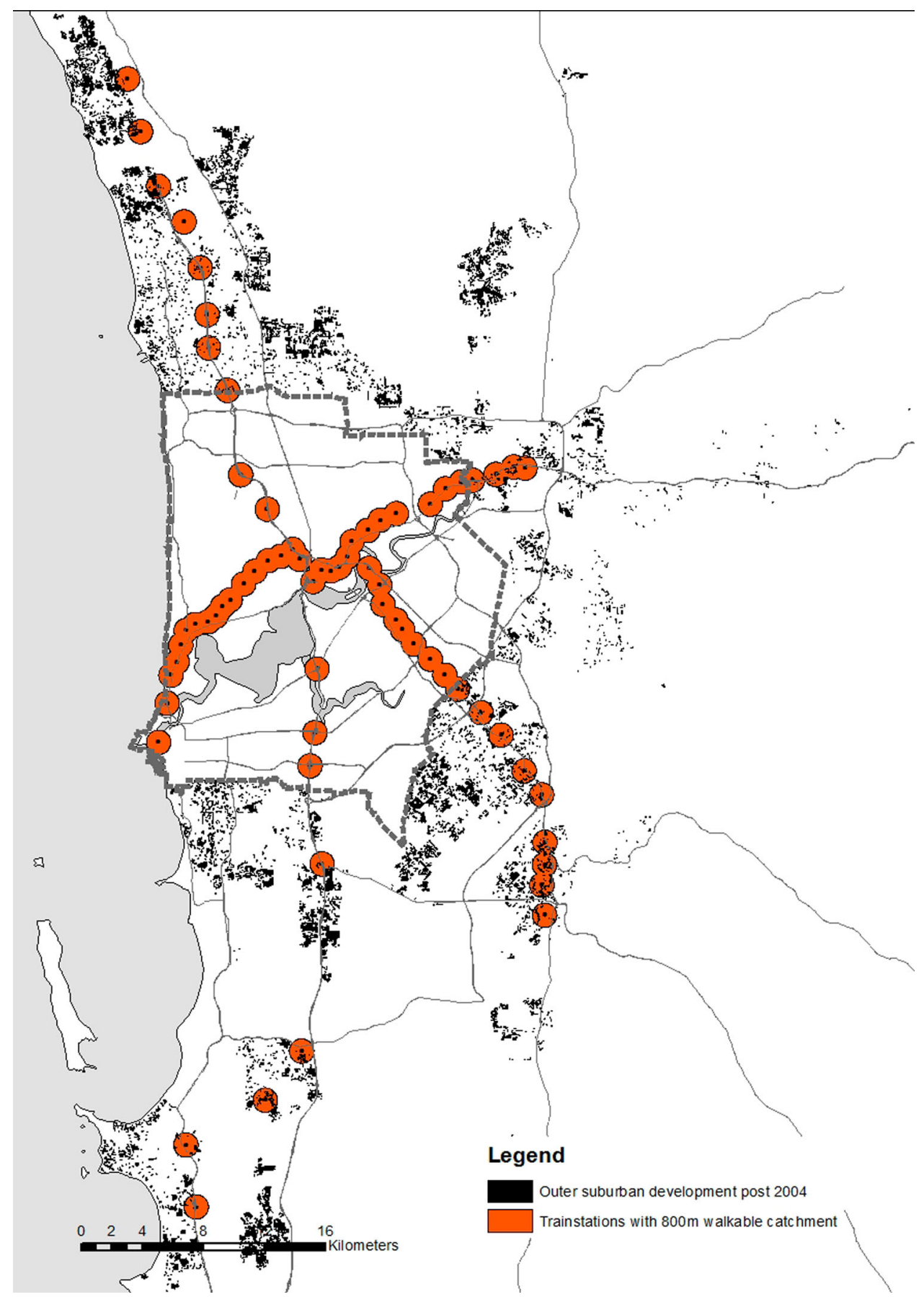

Figure 10. Mapping of Perth's train stations in combination with recent outer suburban development which has occurred since 2004, reveals that little of this urban development is within a comfortable walk of train stations- in this map shown as an $800-$ metre or 10-minute walk.

comfortable, and large capacity gains may be available with vehicle-to-vehicle and vehicle-to-infrastructure communications technology' (Grace, Kinghorn, and Thakur 2016, 10). Indeed a cent KPMG study estimates that these technologies could increase roadway capacity by up to $60 \%$ on freeways, but only by $15 \%$ on arterial roads (Grace, Kinghorn, and Thakur 2016, 10). Certainly Perth's outer suburbs are generally well serviced by freeways and arterial roads suited to FAVs. There is a concern however that due to the increased comfort and convenience of FAVs, commuters may be willing to accept longer travel times (Grace,
Kinghorn, and Thakur 2016, 3) and as such may irrigate further outer suburban expansion (Grace, Kinghorn, and Thakur 2016, 9) - compounding the issues of sprawl on other fronts such as biodiversity loss, bushfire risk and water shortages, discussed previously.

This aside, the literature concerning FAVs proposes that they will have democratising effect (Davis 2016; Somers and Weeratunga 2015) in that 'it doesn't matter if you have a handicap, you are too old or fragile, or too young, or not responsible enough, you'll still have the same mobility options' (Davis 2016, 182). However, it will continue to matter if you can afford to purchase 


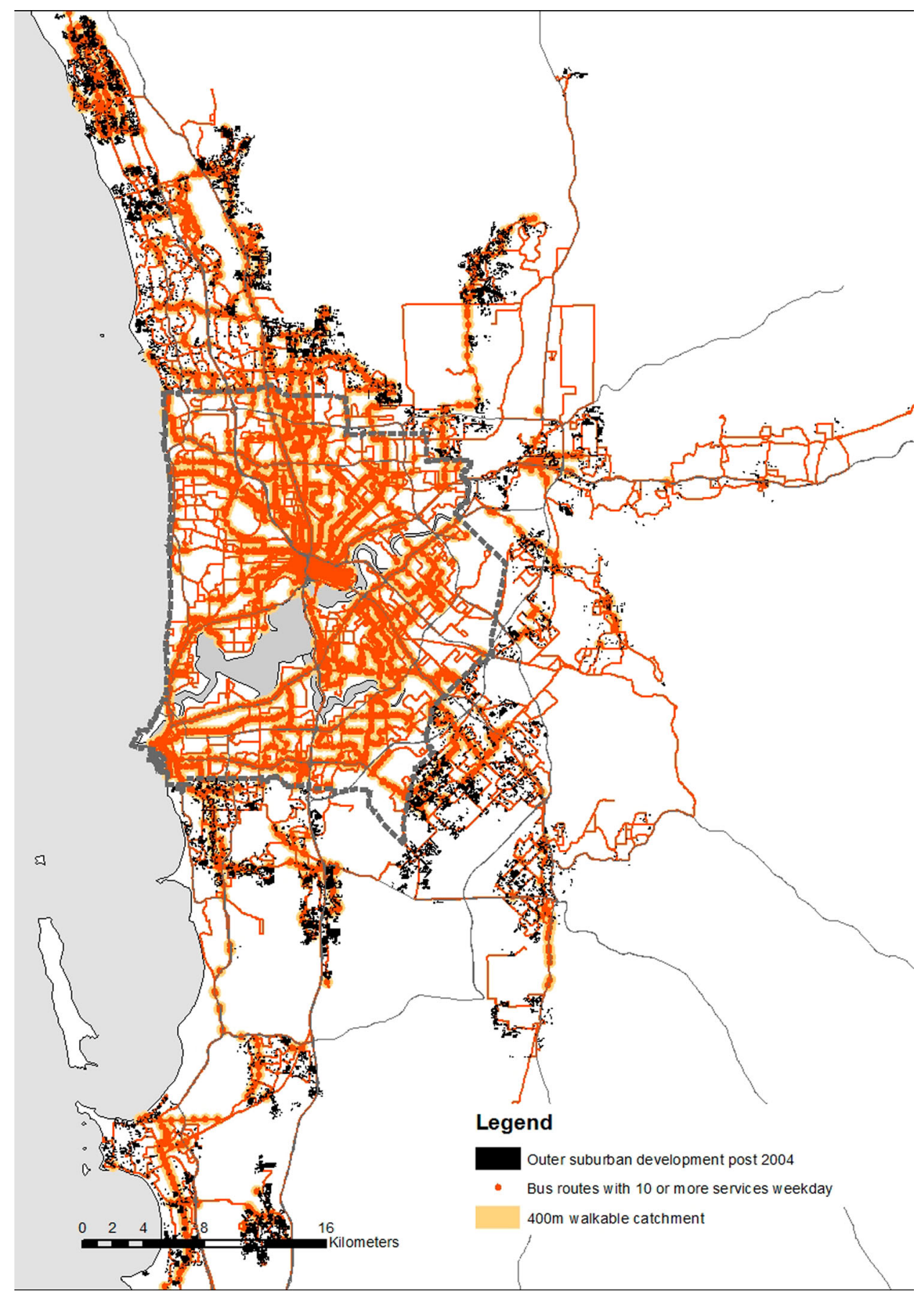

Figure 11. While significantly more of the area of recent outer suburban development is serviced by bus routes than trains, the bus system generally prioritises coverage (meaning short walking distances and the minimisation of bus transfers) over the 'frequency and legibility of the service' (Mees and Dodson 2011, 18) - perhaps explaining the dominant use of vehicles for commuting to work from the other suburbs (Bus stop data courtesy of Government of Western Australia).

one - and there is a legitimate question as to whether outer suburban residents will be able to eco-modernise their fleet of two plus cars (Dodson and Sipe 2008) given the sometimes lower income earning capacity of Perth's outer suburbs (Figure 13) and often comparatively high mortgages.

Much the same can be said of electric cars. Currently low oil prices have, to some degree, eased concerns raised by Dodson and Sipe (2008) regarding the affordability of running multiple (conventional) cars per outer suburban household. However when oil prices inevitably rise it is unlikely that electric vehicles will be affordable for most outer suburban households. Indeed the three major manufacturers currently producing electric vehicles on the Australian market include Nissan (for $\$ 55,000)$, BMW $(\$ 70,000)$ and Tesla $(\$ 130,000)$ (Cormack 2016). In part as a result a recent report for the Energy Supply Association of Australia found that, without government assistance, cumulative electric vehicle sales will only reach 3.4 million vehicles - or 18\% of Australia's vehicle fleet - by 2035 (Cormack 2016). At these take up rates electric cars are 


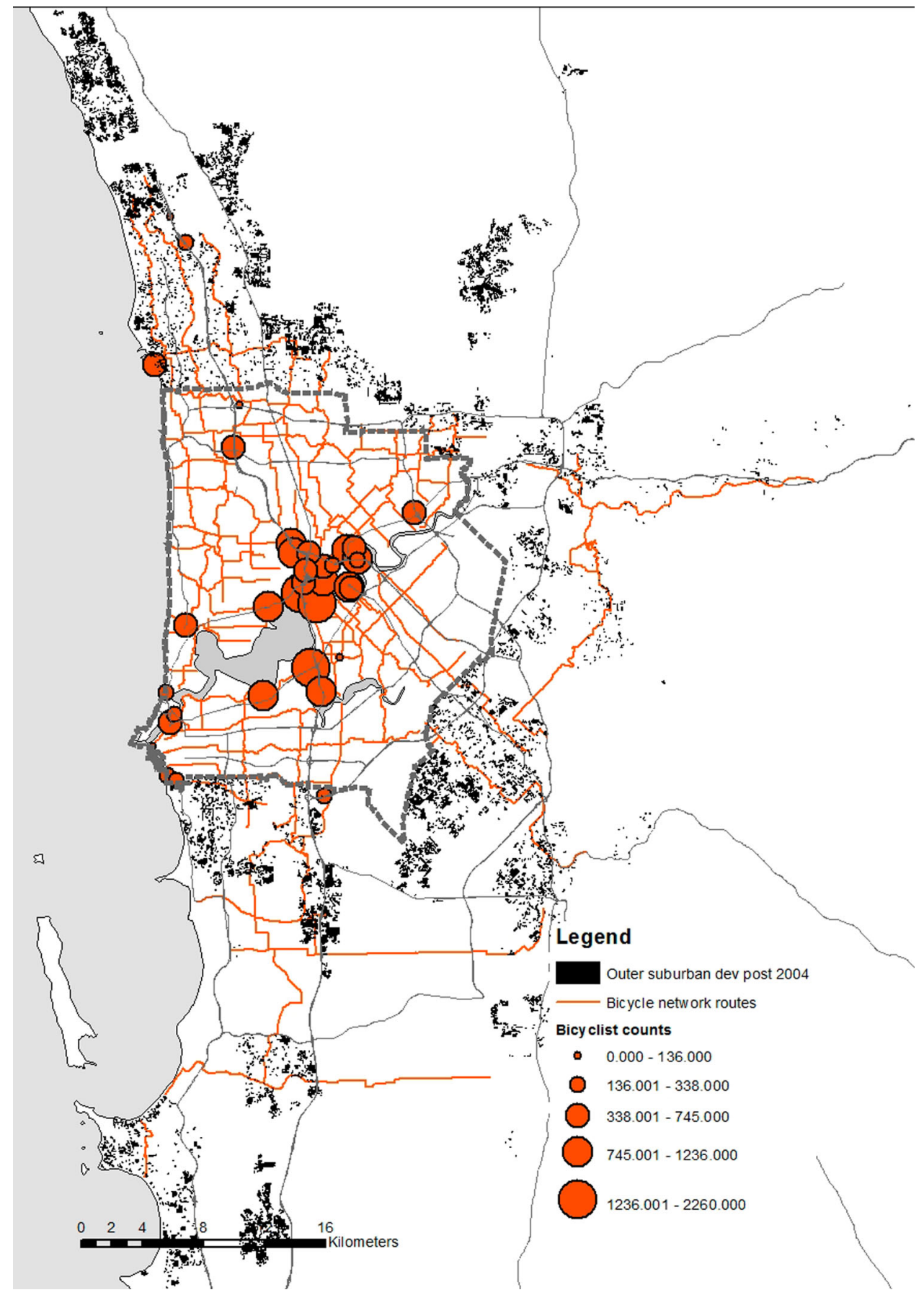

Figure 12. Vehicular dominance in Perth's outer suburban developments is compounded also by an often disconnected and thinly spread bike network, and the significant distance bicycle riders need to cover to even get to major public transport nodes (Bicycle counts and network data courtesy of Government of Western Australia).

unlikely to be the panacea for outer suburban connectivity issues in the near future.

\section{Implications}

The above analysis leads to the conclusion that the state government's goals - from the perspective of access to nature (at a finer lot and street scale) and transport connectivity (public and active) are not necessarily being reached. While access to nature in the form of conservation reserves and POS is generally positive, there are emerging issues in the form of bushfires. Moreover diminished access to nature at the lot and street scale and a lack of public and active transport options are also worrying - particularly with respect to a demographic which is unlikely to be able to eco-modernise their multiple cars to those which are selfdriving and possibly electric. So what are the possible implications of perpetuating such a situation in Perth's outer suburbs?

One is certainly that economic deprivation will be increasingly concentrated in fringe areas. Common indicators of deprivation include income level (both of households and individuals), levels of unemployment and labour force participation, all of which are considered to be direct measures of relative deprivation 


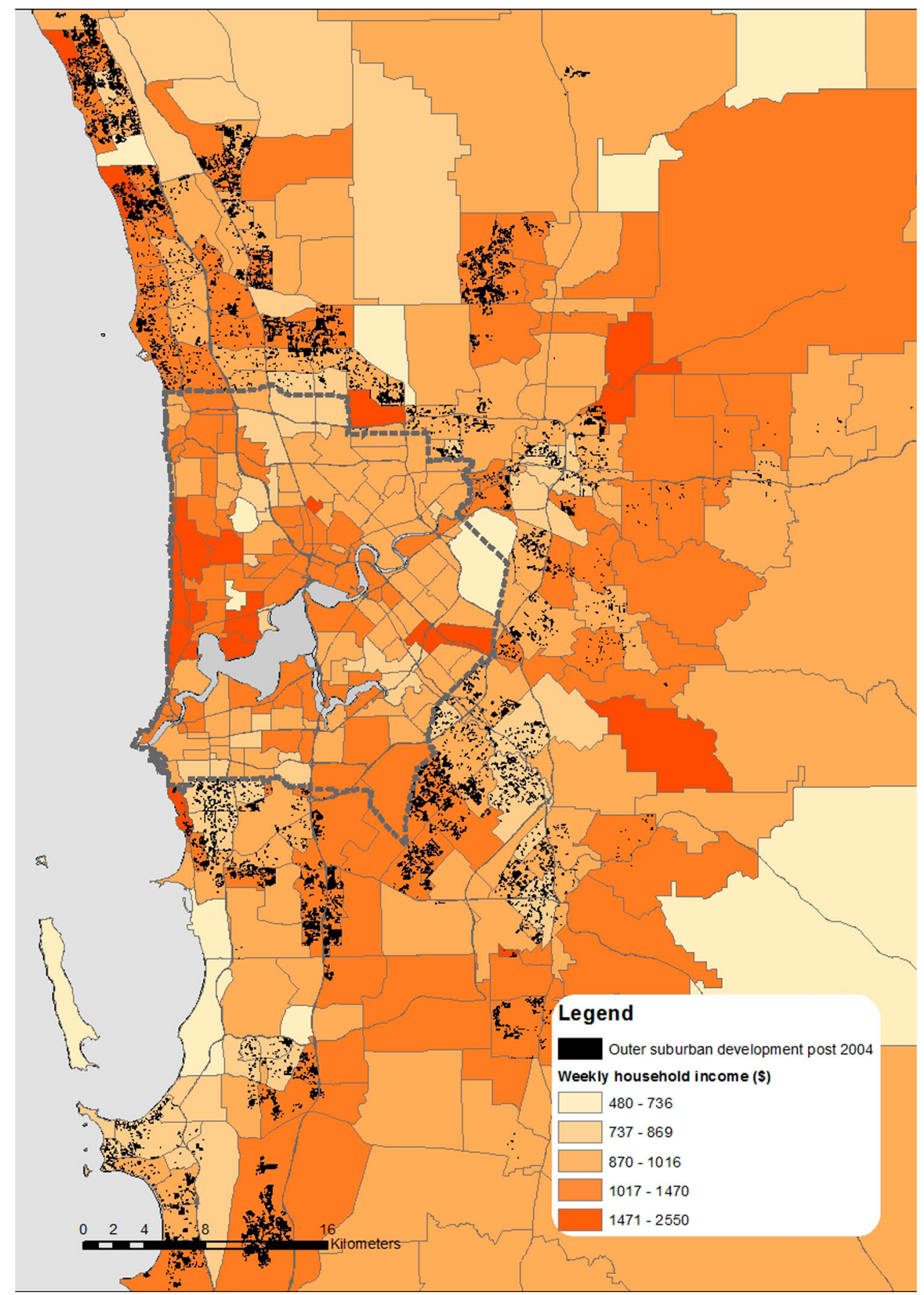

Figure 13. There is a legitimate question as to whether outer suburban residents will be able to eco-modernise their fleet of two plus cars(Dodson and Sipe 2008) - given the sometimes lower income earning capacity of Perth's outer suburbs (Income data courtesy of Australian Bureau of Statistics 2013).

(Baum 2008, 4). Indeed a number of Perth's most economically deprived areas are outer suburbs like Kwinana, Armadale and Two Rocks (Baum 2008, 20) (Figure 14). This concentration of economic deprivation in part reflects the availability of affordable housing on Perth's fringes - put simply people with often less earning capacity live there because that is all they can afford. The consequences of this concentration of deprivation in the outer suburbs will in the long-term effect the city as a whole. Indeed there tends to be a correlation between rising inequalities, social tensions and distrust and the dialectics of order and disorder (Body-Gendrot 2011, 363). As Brendan Gleeson reminds us:

If not stopped, the long slide to a more divided society will surely end in tears. We cannot allow further social polarisation without expecting some serious communal trouble. (Gleeson 2006, 32)

Furthermore, the combination of diminishing access to nature (at a finer scale), and the often absence of viable active transport alternatives to driving, is producing some worrying health data in Perth's outer suburbs (PHIDU Torrens University Australia), and 


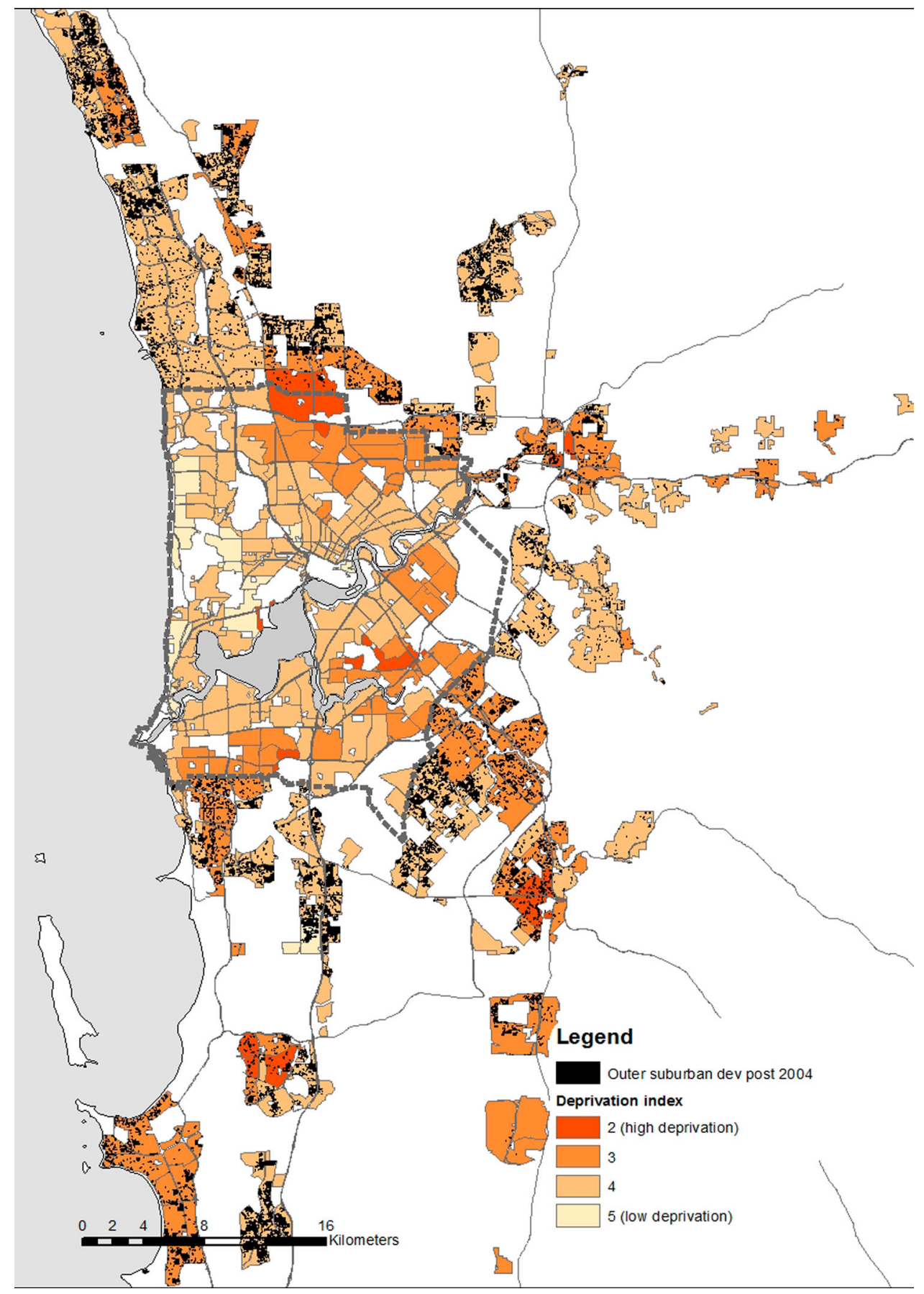

Figure 14. Common indicators of deprivation include income level (both of households and individuals), levels of unemployment and labour force participation, all of which are considered to be direct measures of relative deprivation (Baum 2008, 4). Indeed a number of Perth's most economically deprived areas are outer suburbs like Kwinana, Armadale and Two Rocks (Deprivation data courtesy of Baum 2008, 20).

Australian cities more generally (Adams 2016, 220). In Perth, these include high rates of circulatory disease and diabetes (PHIDU Torrens University Australia). Compounding these physical health issues is also high levels of psychological distress in outer suburban areas. Mapping reveals mental health issues in outer suburban developments are possibly widespread and often up to ten people out of 100 are considered to be in a state of psychological distress ${ }^{8}$ (PHIDU Torrens University Australia) (Figure 15). While to what degree this relates to a lack of connection to nature at a lot or street scale, or isolation due to a lack of connectivity, is unknown - certainly these factors at least compound this situation. The World Health Organisation has predicted that depression will be the second most devastating disease in the world by 2020 (In Gleeson 2016, 12), dethroning the 'emperor of all maladies', cancer (Gleeson 2016, 12) - Perth's outer suburbs would appear to be a premonition of this growing condition.

Given the varied issues facing outer suburban development - relating to access to nature at a finer scale, bushfires, and public transport infrastructure deficits 


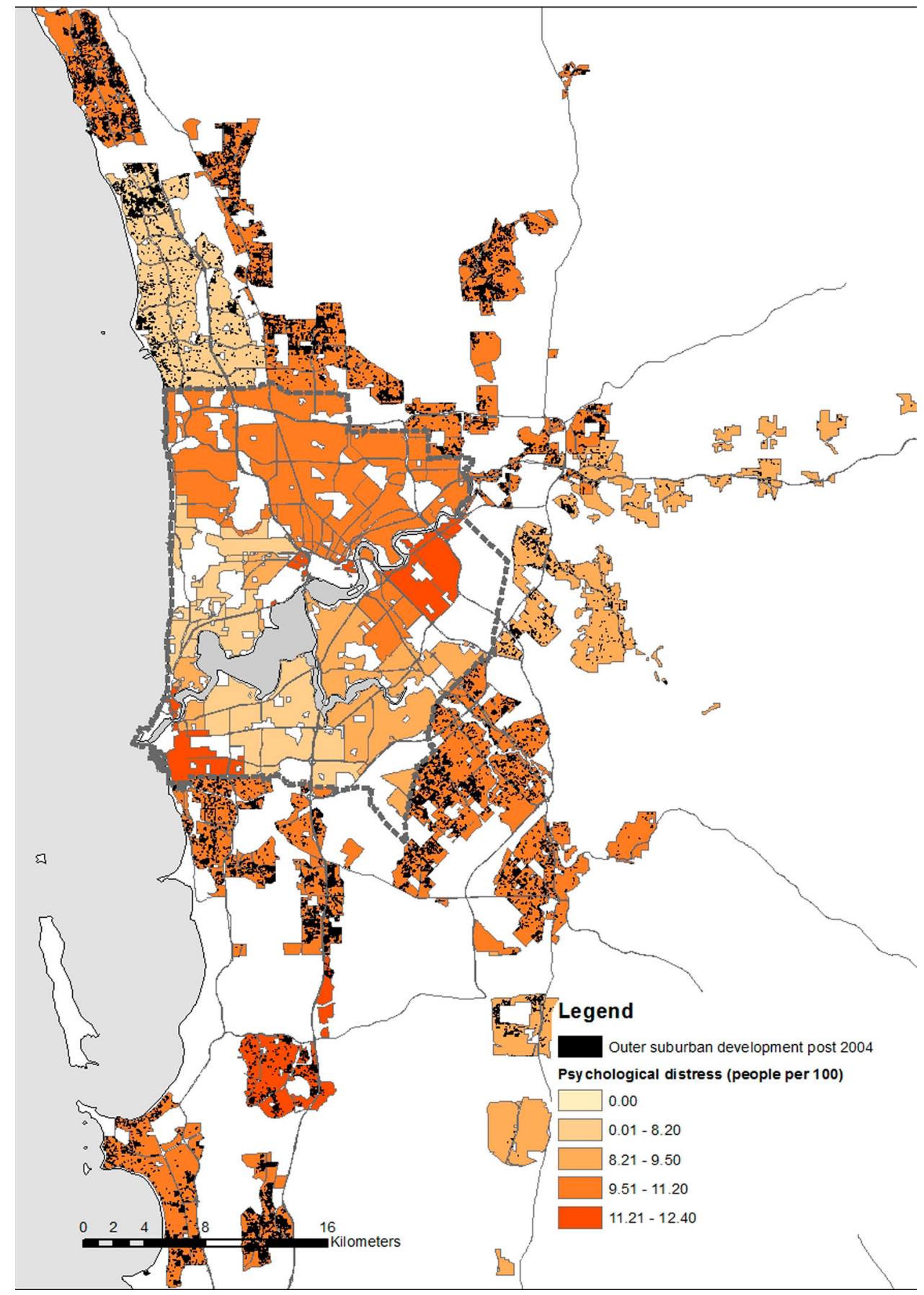

Figure 15. Mapping reveals mental health issues in outer suburban developments are widespread and generally more than 10 people out of 100 are considered to be in a state of psychological distress (Health data courtesy of PHIDU Torrens University Australia).

- I would argue that Perth's modest target for $47 \%$ infill development should be revisited. Indeed this target is the lowest of any Australian capital city - Sydney's target is $50 \%$, Brisbane city up to $90 \%$, Melbourne $53 \%$, Adelaide 70\%, Canberra 50\%, and Hobart 50\% (Bolleter and Weller 2013) - an overall average of $60 \%$. This is particularly the case given that Perth is the Australian city predicted to be most affected by climate change (Flannery in Hedgecock 2010, 102) - which in turn is likely to precipitate water shortages and increased intensity bushfires which will negatively affect the ability to attain the stated state government goals discussed.

\section{Conclusion}

Eminent scientist James Lovelock has declared that in relation to climate change

our leaders should immediately concentrate their minds on sustaining their own nations as a viable habitat; they could be inspired to do this not just out of selfish national interest but also as captains of the lifeboats that their nations might become. (Lovelock 2009, 25)

Based on the analysis set out above, our assessment is that Perth's outer suburbs are not - from certain perspectives - well adapted to be a lifeboat for the city's 
citizens. Indeed as Perth braces for the impact of climate change the dominant urban form that is being produced is one which is vulnerable to the emerging issues discussed.

From a certain perspective, the problem is that the bulk of outer suburban fabric which is being built today, could be with us for many years, and in time 'may have even more negative impacts on the urban communities they are designed to serve than the ones built by the well-intentioned social reformers of the last centuries' (Burdett and Rode 2011, 10). Given Perth's population is predicted to increase dramatically over the next 50 years - from 1.9 to potentially 6.6 million (Australian Bureau of Statistics 2013) - it is vital that the dominant urban patterns which could in time house much of this future population are subject to scrutiny. This paper has been directed towards this end.

\section{Notes}

1. Otherwise known as 'greenfield development' or pejoratively as 'sprawl'.

2. Urban liveability is determined by a wide variety of factors (McCrea and Walters 2012; Rezvani, Mansourian, and Hossain Sattari 2013; Thomas, Walton, and Lamb 2011; Okulicz-Kozaryn 2013; Teo 2014), however because of the necessary brevity of this paper only two have been explored herein.

3. This increased slightly in 2015 to $34 \%$ infill (Department of Planning and Western Australian Planning Commission 2016).

4. This hotspot extends from Geraldton in the north, to Southern Cross in the east, and Esperance in the south.

5. This 2011-2012 PHIDU mapping is based on 'modelled estimates'. The data are self-reported data, reported to interviewers. Physical inactivity is defined as those aged 15 years and over who did not exercise in the two weeks prior to interview for the through sport, recreation or fitness (including walking). Unfortunately there is no more recent data sets for Perth available in relation to physical inactivity.

6. The Department of Water grants local governments an annual water allocation.

7. Tim Flannery, has gone as far as to predict that, due to the declining availability of water, 'Perth will be the 21 st century's first ghost metropolis' (Flannery in Hedgecock 2010, 102).

8. This PHIDU mapping is based on a 'modelled estimate' given as an age-standardised rate per 100 from 2011-2012. Unfortunately there is no more recent mapping for Perth available in relation to psychological distress.

\section{References}

Adams, Toby. 2010. “Taming an Urban Frontier? Urban Expansion and Metropolitan Spatial Plans in Perth
1970-2005." In Planning Perspectives from Western Australia: A Reader in Theory and Practice, edited by I. Alexander, S. Greive, and D. Hedgcock, 33-47. Perth: Fremantle Press.

Adams, Rob. 2016. “The Tale of Two Cities: Four Steps to the Future.” Griffith Review 52: 217-238.

Alexander, Ian, and Shane Greive. 2010. "Metropolitan Development in Perth: Strategic Planning or Strategic Spin?” In Planning Perspectives from Western Australia: A Reader in Theory and Practice, edited by I. Alexander, S. Greive, and D. Hedgcock, 48-65. Perth: Fremantle Press.

Arvola, Anne, and Kyosti Pennanen. 2014. Understanding Residents' Attitudes Towards Infill Development at Finnish Urban Suburbs. In World SB14 Barcelona, edited by Unknown editor. Barcelona: World SB14 Barcelona.

Australian Bureau of Statistics. 2013. Population Projections, Australia, 2012 to 2101. Australian Bureau of Statistics 2013. Accessed January 3, 2013. http://www.abs.gov.au/ ausstats/abs@.nsf/Lookup/3222.0main+features52012\% 20(base)\%20to\%202101.

Badland, Hannah, Carolyn Whitzman, Melanie Lowe, Melanie Davern, Lu Aye, Iain Butterworth, Dominique Hes, and Billie Giles-Corti. 2014. "Urban Liveability: Emerging Lessons from Australia for Exploring the Potential for Indicators to Measure the Social Determinants of Health." Social Science \& Medicine 111: 64-73.

Baum, Scott. 2008. "Suburban Scars: Australian Cities and Socio-Economic Deprivation." Griffith University Urban Research Program (15).

Body-Gendrot, Sophie. 2011. "Uneven Landscapes." In Living in the Endless City, edited by Deyan Sudjic and Ricky Burdett, 360-368. London: Phaidon Press.

Bolleter, J., and R. Weller. 2013. Made in Australia: The Future of Australian Cities. Perth: University of Western Australia Press.

Bruegmann, Robert. 2005. Sprawl: A Compact History. Chicago: The University of Chicago Press.

Brunner, Julie, and Paul Cozens. 2013. "Where Have All the Trees Gone?' Urban Consolidation and the Demise of Urban Vegetation: A Case Study from Western Australia." Planning Practice \& Research 28 (2): 231-255.

Burdett, Ricky, and Phillipp Rode. 2011. "Living in the Urban Age." In Living in the Endless City, edited by Deyan Sudjic and Ricky Burdett, 8-25. London: Phaidon Press.

Centre for the Built Environment and Health, and Gaia Resources. 2013. Positive Places POS Tool. Perth: Centre for the Built Environment and Health.

Conservation International. 2014. Hotspots. Conservation International 2014. Accessed October 30, 2014. http:// www.conservation.org/How/Pages/Hotspots.aspx.

Cormack, Lucy. 2016. "Electric Vehicle Uptake in Australia Held Back by Price, Infrastructure." The Sydney Morning Herald 2016. Accessed September 21, 2016. http://www.smh.com.au/business/consumer-affairs/ electric-vehicle-uptake-in-australia-held-back-by-priceinfrastructure-20160610-gpgkn6.html.

Curtin University and Hames Sharley. 2013. The Housing We'd Choose: A Study for Perth and Peel. Perth: Department of Housing, Department of Planning.

Davis, Tony. 2016. "Revolution on Wheels: Will Australia be Participant or Spectator?." Griffith REVIEW 52: 179-224. Department of Fire \& Emergency Services. 2016. "Map of Bush Fire Prone Areas." In. Perth: Government of Western Australia. https://www.dfes.wa.gov.au/ 
regulationandcompliance/bushfireproneareas/Pages/ default.aspx.

Department of Planning, and Western Australian Planning Commission. 2014. Urban Growth Monitor: Perth Metropolitan, Peel and Greater Bunbury Regions. Perth: Western Australian Planning Commission.

Department of Planning, and Western Australian Planning Commission. 2015. Draft Perth and Peel @3.5 Million. Perth: Western Australian Planning Commission.

Department of Planning, and Western Australian Planning Commission. 2016. Urban Growth Monitor: Perth Metropolitan, Peel and Greater Bunbury Regions. Perth: Western Australian Planning Commission.

Department of Sport and Recreation. 2012. Classification Framework for Public Open Space. Perth: Department of Sport and Recreation.

Department of Transport, Planning and Local Infrastructure, Public Transport Authority and Main Roads WA. 2016. Transport @3.5 Million: Perth Transport Plan. Perth: Government of Western Australia.

Department of Water. 2016. Water for Growth: Urban. Perth: Government of Western Australia.

Dodson, Jago, and Neil Sipe. 2008. Unsettling Suburbia: The New Landscape of Oil and Mortgage Vulnerability in Australian Cities. Brisbane: Griffith University.

Dovey, Kim, and Ian Woodcock. 2014. Intensifying Melbourne: Trasit-Orientated Urban Design for Resilient Urban Futures. Melbourne: Melbourne School of Design, The University of Melbourne.

Duckworth-Smith, Anthony. 2016. Sprawl and the City: Combining the Qualities of Suburban and Urban Living to Create Better Residential Infill. Perth: University of Western Australia.

Gleeson, Brendan. 2006. "Waking from the Dream: Towards Urban Resilience in the Face of Sudden Threat." Griffith University Urban Research Program.

Gleeson, Brendan. 2010. Lifeboat Cities. Sydney: UNSW Press.

Gleeson, Brendan. 2016. "To a New Babylon: Wide-Eyed Humanism and Cautious Pessimism.” Griffith Review 52: 11-78.

Government of Western Australia. 2015. Draft Perth and Peel Green Growth Plan for 3.5 Million: Summary. Perth: Government of Western Australia.

Grace, Renan, Robert Kinghorn, and Praveen Thakur. 2016. "Urban Form and Function in the Autonomous Era." Paper read at Australasian Transport Research Forum 2016, at Melbourne.

Hedgecock, David. 2010. "Watering a Thirsty City: Planning for Perth's Water Regime.” In Planning Perspectives from Western Australia: A Reader in Theory and Practice, edited by I. Alexander, S. Greive, and D. Hedgcock, 85103. Perth: Fremantle Press.

Holling, C., and F. Haslam McKenzie. 2010. "Integrated Transit Orientated Development: Is it Appropriate for Perth?" In Planning Perspectives from Western Australia: A Reader in Theory and Practice, edited by I Alexander, S Greive, and D Hedgcock, 274-288. Perth: Fremantle Press.

Hopper, Stephen, and Paul Gioa. 2004. “The Southwest Australian Floristic Region: Evolution and Coservation of a Global Hotspot of Biodiversity." Annual Review of Ecology, Evolution, and Systematics 35: 623-650.

Kelly, J.-F., P. Breadon, C. Davis, A. Hunter, P. Mares, D. Mullerworth, and B. Weidmann. 2012. Social Cities. Melbourne: Grattan Institute.
Kunstler, James. 1993. The Geography of Nowhere: The Rise and Decline of America's Man-Made Landscape. New York: Simon \& Schuster.

Lovelock, James. 2009. The Vanishing Face of Gaia: A Final Warning. New York: Basic Books.

Martinus, Kirsten. 2014. Spatial Inequality Across Perth and Peel: Stabilising Post-GFC. Perth: Committee for Perth.

McCrea, Rod, and Peter Walters. 2012. "Impacts of Urban Consolidation on Urban Liveability: Comparing an Inner and Outer Suburb in Brisbane, Australia." Housing, Theory and Society 29 (2): 190-206.

McDonald, Robert. 2015. Conservation for Cities: How to Plan and Build Natural Infrastructure. Washington: Island Press.

Mees, Paul, and Jago Dodson. 2011. "Public Transport Network Planning in Australia: Assessing Current Practice in Australia's Five Largest Cities." Griffith University Urban Research Program 34: 1-28.

Middle, Gary, and Marian Tye. 2011. Emerging Constraints for Public Open Space in Perth Metropolitan Suburbs. Perth: Department of Sport and Recreation, Centre for Sport and Recreation Research, Curtin University.

O'Connor, Andrew. 2015. WA Budget: 'Billion-Dollar Deficit', Increased Debt, Asset Sales Expected Hallmarks of Economic Blueprint. Australian Broadcasting Commission 2015. Accessed October 19, 2015. http:// www.abc.net.au/news/2015-05-14/wa-budget-deficitdebt-and-asset-sales-expected/6468074.

Okulicz-Kozaryn, Adam. 2013. "City Life: Rankings (Livability) Versus Perceptions (Satisfaction)." Social Indicators Research 110 (2): 433-451.

PHIDU Torrens University Australia. 2016. Social Health Atlases. Torrens University Australia. Accessed September 14, 2016. http://phidu.torrens.edu.au/socialhealth-atlases\# estCBaZ1koZPR8k3.97.

Ramalho, Cristina, Ettienne Laliberte, Pieter Poot, and Richard Hobbs. 2014. "Complex Effects of Fragmentation on Remnant Woodland Plant Communities of a Rapidly Urbanizing Biodiversity Hotspot.” Ecology 95: 143-155.

Rezvani, Mohammad Reza, Hossain Mansourian, and Mohammad Hossain Sattari. 2013. "Evaluating Quality of Life in Urban Areas (Case Study: Noorabad City, Iran)." Social Indicators Research 112 (1): 203-220.

Rowley, Steven, and Peter Phibbs. 2012. Delivering Diverse and Affordable Housing on Infill Development Sites. Melbourne: Australian Housing and Urban Research Institute.

Ruth, Matthias, and Rachel S. Franklin. 2014. "Livability for all? Conceptual Limits and Practical Implications." Applied Geography 49: 18-23.

Seddon, George. 1994. "The Australian Back Yard." In Australian Popular Culture, edited by Ian Craven, 2235. Cambridge: Cambridge University Press.

Somers, Andrew, and Kamal Weeratunga. 2015. Automated Vehicles: Are We Ready? Perth: Main Roads WA.

South West Australia Ecoregion Initiative. 2006. The Southwest Australia Ecoregion: Jewel of the Australian Continent. Perth: South West Australia Ecoregion Initiative.

State of Western Australia. 2010. State Planning Policy 3.1: Residential Design Codes. Perth: State of Western Australia.

Swaffield, Simon, and Elen Deming. 2011. "Research Strategies in Landscape Architecture: Mapping the Terrain." Journal of Landscape Architecture 2011 (Spring): 34-45. 
Syme, Geoffrey, Mark Fenton, and Sheridan Coakes. 2001. "Lot Size, Garden Satisfaction and Local Park and Wetland Visitation." Landscape and Urban Planning 56: 161-170.

Syme, Geoffrey. 2016. Interview with Geoff Syme Editor in Chief Journal of Hydrology.

Teo, Shaun. 2014. "Political Tool or Quality Experience? Urban Livability and the Singaporean State's Global City Aspirations." Urban Geography 35 (6): 916-937.

Thomas, J. A., D. Walton, and S. Lamb. 2011. "The Influence of Simulated Home and Neighbourhood Densification on Perceived Liveability." Social Indicators Research 104 (2): 253-269.

Thompson, Ian. 2011. "Ten Tenets and Six Questions for Landscape Urbanism.” Landscape Research 37 (1): 7-26.

Transperth. 2016. Transperth Journey Planner. Transperth 2016. Accessed September 21, 2016. http://www. transperth.wa.gov.au/Journey-Planner.
Troy, Patrick. 2004. "Saving our Cities with Suburbs." In Griffith Review: Dreams of Land, edited by Julianne Schultz, 115-127. Brisbane: Griffith University.

Weller, Richard. 2008. "Landscape (Sub)Urbanism in Theory and Practice." Landscape Journal 27 (2): 247-267. Weller, Richard. 2009. Boomtown 2050. Perth: University of Western Australia Press.

West Australian Planning Commission, and Department of Planning. 2007. Liveable Neighbourhoods: A Western Australian Government Sustainable Cities Initiative. Edited by West Australian Planning Commission, Perth.

West Australian Planning Commission, and Department of Planning. 2015. Liveable Neighbourhoods. Edited by West Australian Planning Commission, Perth.

Wheeler, Tone. 2010. "Garden Cities of Tomorrow: Upside Down, Inside out and Back to Front." In Griffith Review 29: Prosper or Perish, edited by Julianne Schultz, 46-56. Brisbane: Griffith University. 